\title{
Platyceratid gastropods - stem group of patellogastropods, neritimorphs or something else?
}

\author{
JiŘí FrÝda, PATRICK R. RaCheboeuf, Barbora FrÝdová, LenKa Ferrová, Michal Mergl \& \\ STANISLAVA BERKYOVÁ
}

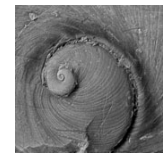

\begin{abstract}
A systematic study of Silurian and Devonian platyceratid gastropods provides new data on their early shell ontogeny. Typical cyrtoneritimorph protoconchs were found in Praenatica cheloti (Oehlert \& Oehlert, 1887) from the Lower Devonian strata of Brittany (W France). The same protoconch type, as in Praenatica Barrande in Perner, 1903, was earlier documented in Orthonychia Hall, 1843. Both of the latter taxa have often been considered to be subgenera of Platyceras Conrad, 1840. However, Silurian and Devonian species of Platyceras from the Barrandian area develop quite different protoconchs (orthostrophic and tightly coiled), similar to those found earlier in different species of the family Naticopsidae Waagen, 1880. Current data suggests that Paleozoic platyceratids represent a diphyletic group. The nature of their protoconchs (development of a true larval shell) testifies against the hypothesis that the Paleozoic platyceratids are the stem group for the Patellogastropoda. However, the derivation of modern neritimorphs from Paleozoic "platyceratids" with tightly coiled protoconchs or from the naticopsids seems to be probable. The strongly convolute neritimorph protoconch (apomorphy of neritimorph crown-group) probably originated after the Permian/Triassic mass extinction event, but before the Late Triassic. - Key words: Gastropoda, phylogeny, Platyceratoidea, Neritimorpha, Patellogastropoda, Cyrtoneritimorpha, protoconch morphology.
\end{abstract}

Frýda, J., Racheboeuf, P.R., FrÝdovÁ, B., Ferrová, L., Mergl, M. \& Berkyová, S. 2009. Platyceratid gastropods - stem group of patellogastropods, neritimorphs or something else? Bulletin of Geosciences 84(1), 107-120 (5 figures). Czech Geological Survey, Prague. ISSN 1214-1119. Manuscript received Febuary 9, 2009; accepted in revised form February 23, 2009; published online March 10, 2009; issued March 31, 2009.

Jiři Frýda, Czech Geological Survey, P.O.B. 85, 11821 Prague 1, and Faculty of Environmental Sciences, CULS, 16521 Prague 6, Czech Republic; bellerophon@seznam.cz・Patrick R. Racheboeuf, UMR CNRS 6538, Domaines Océaniques, Université de Bretagne Occidentale, Brest, UFR des Sciences et Techniques, 6, avenue Le Gorgeu, C.S. 93837, F-29238 Brest Cedex 3, France; patrick.racheboeuf@univ-brest.fr • Barbora Frýdová,VÚRV v.v.i., Research Institute, Drnovská 507, 16106 Prague - Ruzynĕ, Czech Republic • Lenka Ferrová \& Stanislava Berkyová, Czech Geological Survey, P.O.B. 85, 11821 Prague 1, Czech Republic • Michal Mergl, University of West Bohemia, Faculty of Education, Department of Biology, Klatovská 51, 30619 Plzeň, Czech Republic; mmergl@kbi.zcu.cz.

The phylogenetic position of fossil animals is often uncertain due to a limited number of characters bearing a phylogenetic signal. This situation is more frequent in extinct animal groups because their anatomical features cannot be inferred from related living taxa, the latter often characterized not only by their morphological, but also by anatomical and genetic data. Difficulties with recognition of the correct phylogenetic position of fossil animals also increase with their geological age. This rule may be well illustrated by fossil members of the class Gastropoda. Gastropods form about 20 percent of all living marine species in Recent marine ecosystems, but the vast majority of their families originated after the crisis at the Cretaceous/Palaeogene boundary (Stanley 2007 and references therein). In addition, Bouchet et al. (2005) showed that the majority of gastropod families are extinct. The phylogenetic position of these extinct gastropods in relation to higher taxa may be inferred only from the morphological features of their fossilized shells. Generally morphological characters of the teleoconchs (i.e., post-metamorphic shells) seems to represent a good character source for species- to family-level taxonomy. However, teleoconchs bear few or no phylogenetic signals useful for analysis of their order-level position. In contrast to the teleoconchs, the pattern of early shell ontogeny as well as the shell microstructure provides data which seems to be more useful for analysis of the higher phylogenetic relationships of fossil gastropods. Studies of living gastropods (e.g., Bandel 1982) showed that the pattern of early shell ontogeny is a good apomorphic character of high-level taxa. Each of four main groups of living orthogastropods (all gastropods excluding the patellogastropods) may be characterized by a unique pattern of early 
shell ontogeny (Bandel 1982, 1997; Ponder \& Lindberg 1997, and references therein). In addition, the shell ontogenetic pattern is very stable for long temporal ranges which make the recognition of major phylogenetic lineages of living gastropods in the past possible. Analysis of these characters in fossil gastropods has shown that all four living orthogastropod clades (Caenogastropoda, Heterobranchia, Neritimorpha, and Archaeogastropoda) may be traced back to the Paleozoic (Bandel 1997; Frýda 1998a-c, 1999; Nützel 1998; Nützel et al. 2000; Bandel 2002a, b; Frýda \& Rohr 2004, 2006; Frýda et al. 2008a, and references therein). Moreover, studies of the shell ontogeny in fossil gastropods have revealed the presence of several Paleozoic gastropod clades which existed for a long time and which were characterized by unique ontogenetic patterns unknown in post-Paleozoic gastropods (Frýda 1999a, Frýda \& Rohr 2004, Frýda et al. 2008a and references therein). However, our knowledge of the shell ontogeny of Paleozoic gastropods is still poor. The present short paper deals with the discovery of protoconchs in Early Devonian platyceratid gastropods from Brittany (France) and is focused mainly on its significance for an understanding of their higher phylogenetic position.

\section{Platyceratids from Brittany}

On-going revision of the large fossil collections of Devonian gastropods from Brittany (W France) revealed an unusually high number of well-preserved shells belonging to different platyceratid taxa. The almost uncoiled shells of Orthonychia protei (Oehlert, 1883) enabled an analysis of the infraspecific variability of shape, size and position of the muscle scar (Frýda et al. 2008b). On the other hand, coiled shells of some platyceratids revealed a well preserved juvenile whorl making the study of their early shell ontogeny possible. Since the discovery of unusual protoconchs in the Early Devonian Vltaviella reticulata Frýda \& Manda, 1997, our efforts to find other platyceratoideans with a well preserved protoconch has been focused on many Silurian and Devonian gastropod faunas from Europe, Asia, Australia and North America. Characteristic cyrtoneritimorph protoconchs were found in some of these faunas, but typically they were isolated or attached to very juvenile shells, which did not provide sufficient shell characters for determination of their specific as well as generic assignments. Platyceratid species are based, like the vast majority of the Paleozoic gastropod species, on adult shells which frequently do not preserve juvenile whorls. Previous research has provided evidence that isolated cyrtoneritimorph protoconchs are very common in Early Paleozoic strata (see discussion in Frýda 1999; Nützel \& Frýda 2003; Nützel et al. 2006, 2007a), however, because of this it is difficult or even impossible to determine to which species or genus the discovered protoconchs belong. The Early Devonian material of Brittany provides a unique opportunity to study well-preserved protoconchs in adult platyceratid shells. Such conditions are very rare even in living marine gastropods.

The platyceratid gastropods described here come from localities NW of Laval in the eastern part of the Massif Armoricain, in the Mayenne department, W France. The locality of La Baconnière is situated about $15 \mathrm{~km} \mathrm{NW}$ of Laval and is famous for its very abundant, well-preserved fossils, among which are numerous gastropods. The best known localities are the La Poupardière and La Jallerie quarries, which are between $1.5 \mathrm{~km}$ and $2.5 \mathrm{~km} \mathrm{~S}$ of La Baconnière. The Saint Roch quarry, $\mathrm{N}$ of Saint Ouendes-Toits, is close to the La Jallerie quarry, and situated about $3 \mathrm{~km} \mathrm{~S}$ of La Baconnière. Maps and a detailed description of the above-mentioned localities can be found in the monographs of Morzadec (1971) and Racheboeuf (1976).

\section{Generic position of platyceratids from Brittany}

Since the middle of the nineteenth century several tens of Early Devonian gastropod species were described from Brittany (e.g., Verneuil 1850; Oehlert 1877, 1881, 1883; Oehlert \& Oehlert 1887; Oehlert \& Davoust 1879; Renaud 1930, 1942). Gastropods placed into the superfamily Platyceratoidea Hall, 1879 form only a small part of the species known from Brittany. Seven gastropod species, described under the names Platyceras lorieri de Verneuil, 1850, Platyceras dentalium Hall, 1861, Platystoma? janthinoides Oehlert, 1877, Platystoma? naticopsis Oehlert, 1877, Diaphorostoma (Strophostylus) cheloti Oehlert \& Oehlert, 1887, Platystoma naticopsis v. undulata Oehlert, 1881, and Acroculia protei Oehlert, 1883 are typical platyceratids. Four additional species - Naticopsis sirodoti Munier-Chalmas, 1876, Naticopsis filosa Oehlert \& Oehlert, 1887, Naticopsis elegantula Oehlert \& Davoust, 1879, and Naticopsis bigsbyi Oehlert \& Davoust, 1879 - described as belonging to the genus Naticopsis M'Coy, 1844, may also be members of the platyceratoidean group. The generic position of Platyceras lorieri, Platyceras dentalium and Acroculia protei is obvious (see Oehlert 1881, pl. II, and Frýda et al. 2008a) and they may be placed in the genus $O r$ thonychia Hall, 1843. In addition, the first two species may be even conspecific (see de Verneuil, 1850, pl. II, figs 1, 2). The core group of the platyceratids from Brittany is formed by Diaphorostoma (Strophostylus) cheloti, Platystoma? janthinoides, Platystoma? naticopsis and Platystoma naticopsis v. undulata. In 1877, Oehlert described two species from the locality La Baconnière which he questionably placed in the genus Platystoma (later correctly cited by 

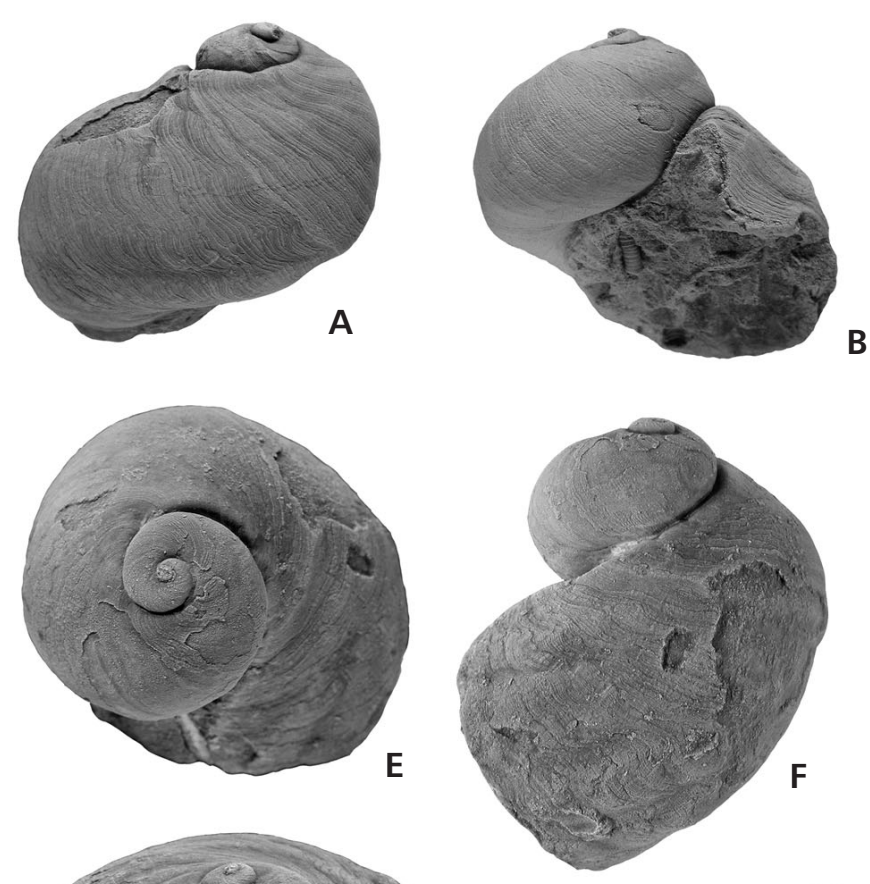

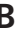
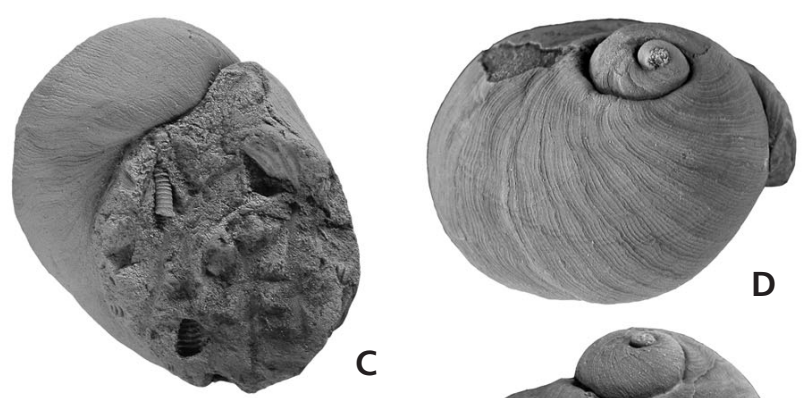

C
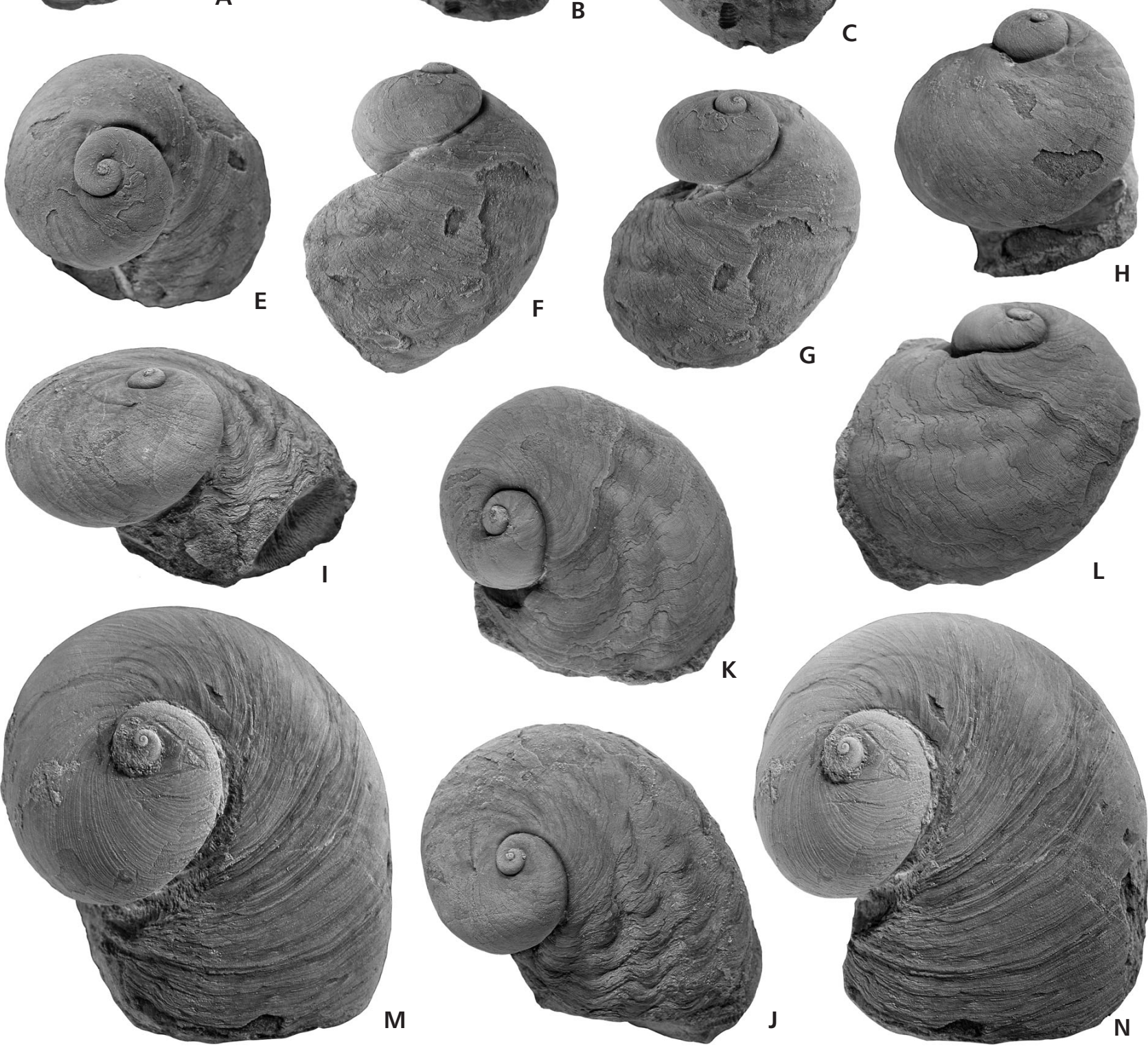

J

西

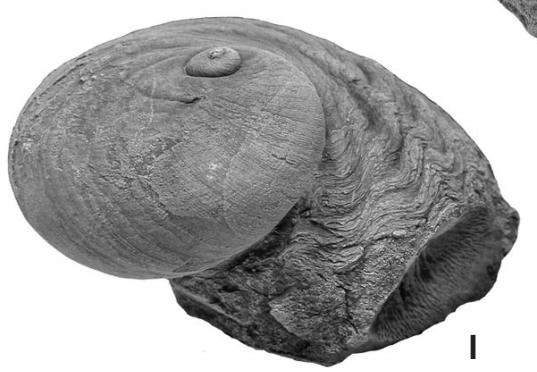

Figure 1. Platystoma? naticopsis [= Praenatica naticopsis] Oehlert, 1877 and Diaphorostoma (Strophostylus) cheloti [= Praenatica cheloti] Oehlert \& Oehlert, 1887 from the Lower Devonian strata of Brittany (France). • A-D - holotype of Platystoma? naticopsis Oehlert, 1877 [= Praenatica naticopsis] figured on pl. 9, fig. 10, UBO [= Université de Bretagne Occidentale] collection, No. 2560 (Musée d'Histoire Naturelle, Laval, No. ML-PAL-00401), La Poupardière quarry near La Baconnière. • E-H - Praenatica naticopsis from La Baconnière (about $15 \mathrm{~km} \mathrm{NW}$ of Laval), topotype No. ML-PAL-00402 from the same collection as the holotype. $\bullet$ I-J - Praenatica naticopsis from La Baconnière, topotype No. ML-PAL-00403 from the same collection as the holotype. $\bullet \mathrm{K}, \mathrm{L}$ - Platystoma? naticopsis Oehlert, 1877 [= Praenatica naticopsis] figured by Renaud (1942) on pl. IX, fig. 7, UBO collection, No. 2561 (No. ML-PAL-00404), La Poupardière quarry near La Baconnière. • M, N - Diaphorostoma (Strophostylus) cheloti Oehlert \& Oehlert, 1887 [= Praenatica cheloti] from the Saint Roch quarry (about $3 \mathrm{~km} \mathrm{~S}$ of La Baconnière) with preserved cyrtoneritimorph protoconch, No. ML-PAL-00405. All shells $\times 1.5$. 
Oehlert as Platyostoma Conrad, 1842). Both species seem to be very similar (judging from figures and description in Oehlert 1877). On-going revision of these two species from Brittany has resulted in some problems. Only the holotype of Platystoma? naticopsis Oehlert, 1877, (figured on pl. 9, fig. 10 and deposited in the UBO [= Université de Bretagne Occidentale] collection under the number 2560 see Fig. 1A-D) was found. However, the holotype of the second species, Platystoma? janthinoides Oehlert, 1877, which should be in the same collection was not found or was not recognized by the senior author among the many tens of platyceratid specimens (partly not numbered) in the UBO collection and is probably lost. Comparison of those platyceratid specimens with the holotype of Platystoma? naticopsis Oehlert, 1877, revealed that the latter species is rather variable as had already been mentioned by Oehlert (1877). The platyceratids from the locality La Baconnière seem to form a morphological group belonging to one species which also includes the holotypes of Platystoma? naticopsis, Platystoma? janthinoides, and Platystoma naticopsis v. undulata. However, we are leaving this question open until the time when a revision of all platyceratids from Brittany is finished and when the loss of the holotype of Platystoma? janthinoides is confirmed. Later Oehlert, in 1887, described Diaphorostoma (Strophostylus) cheloti also from the locality La Baconnière and mentioned that it differs from his Platyostoma naticopsis by its apertural shape, growth lines, and shell size. However, these shell characters seem to vary during ontogeny in the studied specimens and, therefore, they cannot be used for safe (if any) species-level taxonomy. Thus, Diaphorostoma (Strophostylus) cheloti may also be conspecific with Platyostoma naticopsis (compare specimens figured here in Figs 1 and 2). Regardless of the latter problem, all the abovementioned species belong to the same genus. As mentioned by Knight (1941) Diaphorostoma Fischer, 1885 is an objective synonym for Platyostoma Conrad, 1842. Barrande, in a private letter (May 12, 1882) to Daniel Oehlert, expressed his opinion that some of Oehlert's Platyostoma naticopsis may belong to his new genus Praenatica (Horný \& Henry 1999). However, the name Praenatica was first published by Bigsby (1868) as a nomen nudum and its valid publication by Perner in 1903 is dated much later (see detailed description of that problem by Knight 1941 and Horný \& Henry 1999). We agree with the conclusions made by Barrande (letter of May 12, 1882) and Horný \& Henry (1999) and place all the above-mentioned French species, Diaphorostoma (Strophostylus) cheloti, Platystoma? janthinoides, Platystoma? naticopsis and Platystoma naticopsis v. undulata, in the genus Praenatica. In addition, Praenatica gregaria (Barrande in Perner 1903), a species very common in the Koněprusy Limestone [Praha Formation; Pragian-early Emsian (see Carls et al. 2008), Early Devonian], may also belong to this species as already mentioned by Barrande (letter of May 12, 1882) and Horný \& Henry (1999). We follow here this generic placement for the taxa from Brittany, but leave their species-level revision for future study.

\section{Early ontogeny of Praenatica}

Several adult shells, some of them determined by Oehlert as Diaphorostoma (Strophostylus) cheloti [= Praenatica cheloti (Oehlert \& Oehlert, 1887)], were found with relatively well preserved protoconchs. The maximum size of the teleoconchs in Praenatica cheloti with preserved protoconchs is $5 \mathrm{~cm}$ (Fig. 2) and the preservation of their protoconchs was probably positively influenced by the muddy facies in which specimens of Praenatica cheloti were found. The protoconchs of Praenatica cheloti are opencoiled, fish-hooklike, and their diameter is about $0.5 \mathrm{~mm}$. The general shape as well as size is constant in these protoconchs (Fig. 3).

A systematic effort to find preserved protoconchs in the Pragian Praenatica gregaria (Barrande in Perner 1903) from the Koněprusy Limestone (Praha Formation, Barrandian area) was not fruitful despite the fact that the senior author examined many hundreds of shells of Praenatica gregaria mainly from the Plešivec Quarry (SE of Koněprusy and SW of Měnany) for that character. The only exception is a specimen found during the revision of Paleozoic gastropods from the Schary collection (a large collection of Paleozoic fossils from the Barrandian area, Czech Republic, deposited since the nineteenth century in the Museum of Comparative Zoology, Harvard University). The latter specimen was labeled as coming from Koněprusy and without doubt it belongs to Praenatica gregaria. In addition, the character of the limestone surrounding the shell indicates its origin from the Koněprusy Limestone. However, the protoconch of the above-mentioned specimen is not completely preserved (its apex is missing), but its remains show a distinct cavity in the center of the first whorl (Fig. 3H, I). Thus, the remains of the protoconch in the Bohemian Praenatica gregaria seem to be identical with the protoconchs of Praenatica cheloti in its size and shape (compare Fig. 3A-F with 3H-I).

\section{Early ontogeny of platyceratid gastropods}

Preservation of early ontogenetic shells of Paleozoic and early Mesozoic gastropods is rare because protoconchs are small, delicate, and aragonitic. Consequently, they are commonly removed from the fossil record by taphonomic and diagenetic processes. For this reason the fossil record of platyceratid protoconchs is relatively poor, similar to that of all other Paleozoic gastropods. A systematic effort to 

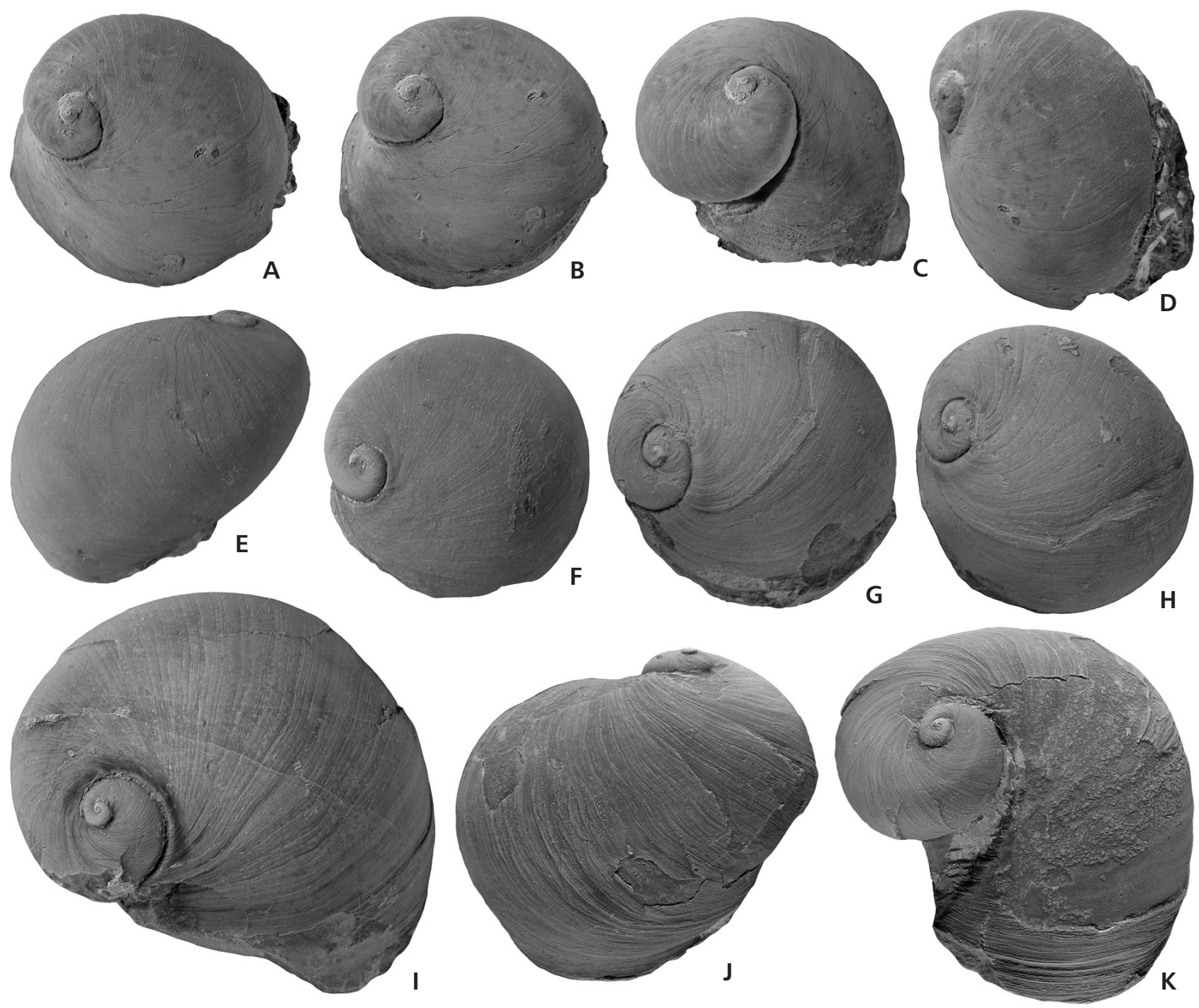

Figure 2. Diaphorostoma (Strophostylus) cheloti [= Praenatica cheloti] Oehlert \& Oehlert, 1887 from the Lower Devonian strata of Brittany (France). - A-D - Praenatica cheloti from the Saint Roch quarry ( $\mathrm{N}$ of Saint Ouen-des-Toits and about $3 \mathrm{~km} \mathrm{~S}$ of La Baconnière), the same specimen or a specimen similar to that figured by Oehlert \& Oehlert (1887) on pl. VI, fig. 8c (Musée d'Histoire Naturelle, Laval, No. ML-PAL-00406); the shell is in a dark grey limestone with white brachiopods and has a well preserved cyrtoneritimorph protoconch (see Fig. 3A-C). $\bullet$, F - Praenatica cheloti from the same limestone type as Fig. 2A-D and labeled as coming from La Baconnière, collection ML 06883 (No. ML-PAL-00407). • G, H - paratype of Diaphorostoma (Strophostylus) cheloti [= Praenatica cheloti] figured on pl. VI, fig. 8b by Oehlert \& Oehlert (1887), UBO collection, No. 2562 (No. ML-PAL-00408), the Saint Roch quarry (N of Saint Ouen-des-Toits and about $3 \mathrm{~km} \mathrm{~S}$ of La Baconnière). $\bullet \mathrm{I}-\mathrm{K}$ - two shells of Praenatica cheloti from the Saint Roch quarry, topotypes No. ML-PAL-00409 (I) and No. ML-PAL-00410 (J, K) from the same limestone type as Fig. 2A-D. All shells $\times 1$.

find preserved protoconchs in members of the family Platyceratidae resulted in several unexpected discoveries. Frýda (1998a, b, 1999) provided evidence that teleoconchs of some presumed platyceratid gastropods bear unusual protoconchs with openly coiled, fish-hooklike morphology and these protoconch types may be traced from the Early Ordovician to the Late Permian, thus, lasting for about 250 million years. He interpreted this group as an independent gastropod lineage, which may represent an ancestral group for Neritimorpha, and therefore named it Cyrtoneritimorpha (Frýda 1998a-c, 1999). Cyrtoneritimorph protoconchs are relatively common in the Ordovician, Silurian and Lower Devonian strata, but during the Carboniferous and Permian they became rare and no record exists for them in post-Paleozoic times (Frýda \& Manda 1997, Frýda 1999, Frýda \& Bandel 1999, Heidelberger \& Bandel 1999, Frýda \& Heidelberger 2003). Even though cyrtoneritimorph protoconchs are common in the Early Paleozoic, there are only a few examples with the protoconch found in an adult teleoconch, making species-level determination possible. Up to now, cyrtoneritimorph protoconchs were found in the following species - Silurian Krameriella hornyi Frýda \& 
Heidelberger, 2003; Devonian Vltaviella reticulata Frýda \& Manda, 1997; Soetenichia girzenbergense (Kirchner, 1915); Eifelcyrtus blodgetti Frýda \& Heidelberger, 2003; Praenatica cheloti (Oehlert \& Oehlert, 1887); Carboniferous Orthonychia parva (Shumard \& Swallow, 1858); and Permian Orthonychia bowsheri Yochelson, 1956 (Fig. 5). However, there is very rich fossil material of isolated cyrtoneritimorph protoconchs from different stratigraphical levels of Ordovician to Lower Devonian strata showing that the cyrtoneritimorphs were common in the Early $\mathrm{Pa}-$ leozoic gastropod faunas. Open-coiled protoconchs were found in several clades of Paleozoic gastropods such as the Euomphalomorpha, Peruneloidea, Macluritoidea, and Cyrtoneritimorpha (Frýda 1999; Bandel \& Frýda 1998, 1999; Nützel 2002; Frýda \& Rohr 2004, 2006; Frýda et al. 2008a). A documented general trend towards decreasing proportions of open-coiled protoconchs through the Paleozoic may also explain the decrease in frequency of cyrtoneritimorph protoconchs (Nützel \& Frýda 2003; Frýda et al. 2008a).

On the other hand, in addition to the cyrtoneritimorph protoconchs, Frýda (1998a,b, 1999) reported the occurrence of tightly coiled, but not convolute, orthostrophic protoconchs in some Paleozoic "platyceratoidean" gastropods. Such protoconch morphology was later documented in some members of the Platyceratidae, Plagiothyridae, Naticopsidae, Nerrhenidae, and Oriostomatoidea (Yoo 1994, Bandel \& Frýda 1999, Bandel \& Heidelberger 2001, Nützel \& Mapes 2001, Nützel et al. 2007a). Some new findings also revealed this protoconch type in "Platyceras" sp. from the Chýnice Limestone (middle Emsian; Devonian) of the Barrandian area (Fig. 4A-C). Similar early shell morphology was found in the Upper Silurian "Platyceras" sp. from the same area (see Fig. 4E, F, H, I). Even though the first shell whorl is not preserved in any of the Silurian specimens, the shape and small size of the youngest whorl shows that they don't possess a cyrtoneritimorph protoconch.

The fact that two quite different protoconch morphologies occur in Devonian platyceratids (compare Figs 3 and 4) suggests that they do not form a monophyletic group. This conclusion seems to be also supported by the very long stratigraphic range of the cyrtoneritimorph protoconchs which can be traced from the Early Ordovician to the Late Permian, an interval of 250 million years duration (Frýda 1998a-c, Bandel \& Frýda 1999, Frýda \& Rohr 2004). The existence of two, not closely related groups complicates analysis of the phylogenetic position of platyceratid gastropods within the class Gastropoda. In addition, this situation also resulted in a nomenclatorial problem - it is uncertain what family-level names should be used for these gastropods. The genus Platyceras Conrad, 1840, is based on Platyceras vetusta (Sowerby, 1829) from the Lower Carboniferous of Queens Country, Ireland. The protoconch of this species is unknown and so there is no evidence for its placement either in the Cyrtoneritimorpha or in "platyceratids" having tightly coiled, orthostrophic protoconchs. If the type species of Platyceras has a tightly coiled, orthostrophic protoconch like the Silurian and Devonian "Platyceras" sp. illustrated here (Fig. 4A-C, E, F, H, I), then the model proposed by Bandel \& Frýda (1999) may be accepted (see also Bouchet et al 2005). The Platyceratidae will include platyceratid gastropods with tightly coiled, orthostrophic protoconchs similar to those found in the Paleozoic Naticopsidae (Yoo 1994, Nützel \& Mapes 2001, Bandel 2002a, Nützel et al. 2007a). Moreover, the families Vltaviellidae Bandel \& Frýda, 1999, and Orthonychiidae Bandel \& Frýda, 1999, will unite "platyceratid" gastropods with cyrtoneritimorph protoconchs. But if the type species of Platyceras also has a cyrtoneritimorph protoconch like Praenatica or Orthonychia, then the families Vltaviellidae and Orthonychiidae may represent junior synonyms of the Platyceratidae. Note that a similar situation occurs in the genus Orthonychia (being often considered to represent a subgenus of Platyceras), which is based on the Devonian species Orthonychia subrectum (Hall, 1859), which also has an unknown protoconch morphology. Protoconchs of Paleozoic species of Orthonychia have cyrtoneritimorph morphology (e.g., Fig. 5C, D). However, Triassic Orthonychia alata (Laube 1869) has the typical protoconch of post-Paleozoic neritimorphs. For this reason the species was placed into a new genus Pseudorthonychia Bandel \& Frýda, 1999.

\section{Platyceratids as a stem group of neritimorphs}

Knight et al. (1960) considered the Platyceratoidea to represent an independant superfamily of the Trochina and, thus, placed them into the Archaeogastropoda. However, not only Platyceratoidea, but all neritimorphs were traditionally placed in the archaeogastropods mainly because they share a rhipidoglossate radula with the vetigastropods (e.g., Troschel 1856, Thiele 1929-35, Wenz 1938-44, Knight et al. 1960). Bandel (1982) studied in detail the ontogeny and protoconch morphology of extant neritimorphs and he concluded that they represent a separate evolutionary lineage which is distinct from other archaeogastropods. This conclusion was later supported by anatomical and molecular data (e.g, Haszprunar 1988, Healey 1988, Sasaki 1998, Ponder \& Lindberg 1997, Kano et al. 2002). Ponder \& Lindberg (1997), similar to Haszprunar (1988), considered the Neritimorpha to represent an "early archaeogastropod offshoot", thus, the neritimorphs according to their interpretation form a sister group of all gastropods except the Patellogastropoda. The latter model resulted in the conclusion that planktotrophy originated twice in the 


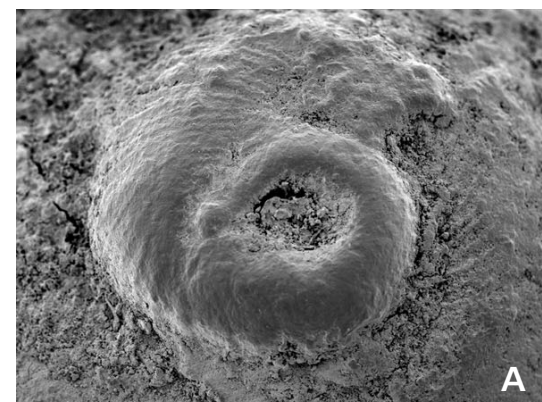

A
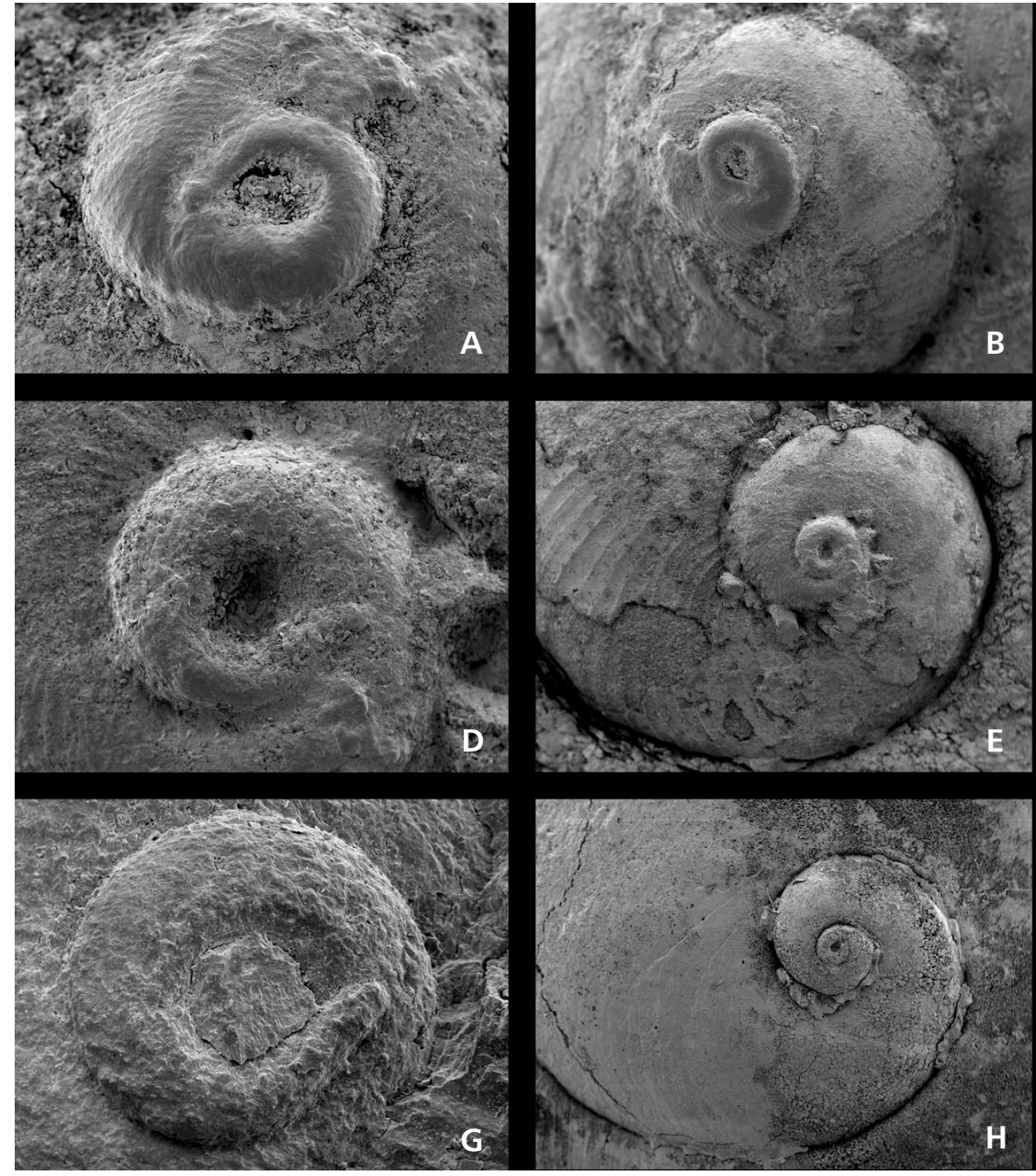

B
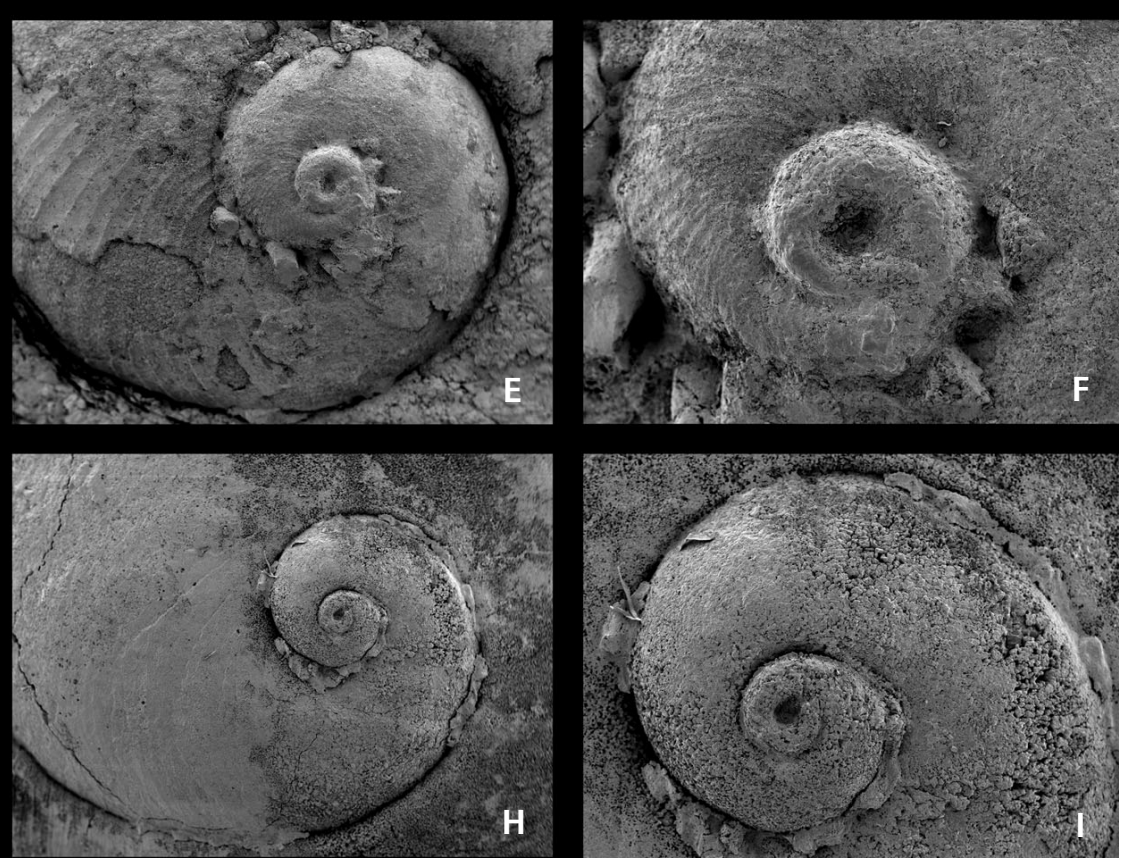

Figure 3. Cyrtoneritimorph protoconchs in species of Praenatica Barrande in Perner, 1903, and Krameriella Frýda \& Heidelberger, 2003. - A-C - cyrtoneritimorph protoconch in Praenatica cheloti (Oehlert \& Oehlert, 1887) from the Saint Roch quarry (N of Saint Ouen-des-Toits and about $3 \mathrm{~km} \mathrm{~S}$ of La Baconnière) figured here as Fig. 2A-D, A $\times 42, \mathrm{~B} \times 18, \mathrm{C} \times 50 . \cdot \mathrm{D}-\mathrm{F}-$ cyrtoneritimorph protoconch in Praenatica cheloti (Oehlert \& Oehlert, 1887) from La Baconnière, topotype No. ML-PAL-00411, D × 60, E × 13, F × 37. • G - cyrtoneritimorph protoconch in holotype of the Silurian Krameriella hornyi Frýda \& Heidelberger, 2003, from the Kopanina Formation (Gorstian, early Ludlow, early Late Silurian) of the Barrandian area, G $\times 95$. $\bullet$ H, I - fragment of cyrtoneritimorph protoconch in Early Devonian Praenatica gregaria Barrande in Perner, 1903, from the Koněprusy Limestone (Praha Formation, Pragian-lower Emsian) of the Barrandian area, the Schary collection No. 193178, the Museum of Comparative Zoology, Harvard University, $\mathrm{H} \times 9, \mathrm{I} \times 21$.

evolution of the Gastropoda (Haszprunar 1995), in the Neritimorpha and in the Apogastropoda (uniting Caenogastropoda and Heterobranchia). New molecular studies, however, supported the earlier published position of the Vetigastropoda as a sister group of the Neritimorpha, Caenogastropoda and Heterobranchia, as well as the monophyly of the Neritimorpha (Colgan et al. 2003, McArthur \& Harasewych 2003, Kano et al. 2002, Aktipis et al. 2008).

The Paleozoic platyceratoidean gastropods were considered to belong to the Neritimorpha (Bandel 1992, Bandel \& Frýda 1999, Frýda 1999). Besides their general shell shape, the presence of a thick calcitic outer shell layer (Batten 1984) often bearing coloured bands (Yochelson 1956, Kříž \& Lukeš 1974, Yochelson \& Kříž 1974, Blodgett \& Johnson 1992) seems to be conformable with this view. However this opinion could not be tested by the shape of their protoconchs. The oldest evidence for neritimorph protoconchs of the same type as is found in living marine neritimorphs (see Bandel 1982) was documented in the Upper Triassic (Bandel \& Frýda 1999, Bandel 2007, and references therein). Bandel (2007) showed that several groups of the neritimorphs can be traced from the Triassic to Recent and that species diversity of neritimorphs was much higher in the Triassic reef environment than in any modern reefs. He documented 36 neritimorph species from tropical reefs of the Late Triassic St Cassian Formation in the Tethys Ocean. Only the living species of Neritopsis can be regarded as relatively closely related to some of these species from the Cassian Reef. Bandel (2007) noted that other Triassic species can 
be placed into the superfamilies Neritopsoidea and Neritioidea, but not in any of the modern families. On the other hand, according to this author some Triassic neritimorphs (subfamilies Ampezzonaticopsinae Bandel, 2007 and Hologyrinae Bandel, 2007) belong to the family Naticopsidae. The latter family was highly diverse from Devonian to Permian time. The genus Naticopsis M'Coy, 1844 is based on Naticopsis phillipsii M'Coy, 1844 from the Lower Carboniferous of Ireland and as is typical for Paleozoic gastropods in that its protoconch as well as its shell structure are unknown. Bandel (2007) noted that the naticopsid lineage is extinct, thus, it has no connection to modern Neritimorpha, similar to the vast majority of Late Triassic neritimorphs.

There is no evidence in the Paleozoic for the presence of the characteristic, strongly convolute neritimorph protoconchs (representing an apomorphy of the neritimorph crown group). On the other hand, there is rich evidence for the high diversity and morphological disparity of the neritimorphs having this protoconch type in the Late Triassic (Bandel 2007). These facts suggest that the strongly convolute larval shell of the neritimorphs (protoconch II) originated after the Permian/Triassic mass extinction event and before the Late Triassic. An analysis of the neritimorph phylogeny published by Kaim \& Sztajner (2005) and mainly based on operculum morphology resulted in similar conclusions (see also Kano 2006, Bandel 2008). According to the latter authors, modern Neritimorpha split into Neritidae (internally resorbed) and Neritopsidae (not resorbed) at the Paleozoic/Mesozoic transition. Molecular studies also provide evidence for the basal position of the Neritopsidae, thus, it represents a sister group of all living Neritimorpha (Kano et al. 2002). This model fits well with the post-Paleozoic fossil record.

However which Paleozoic group is ancestral to the Neritimorpha? Knight (1933) and Knight et al. (1960) suggested that the Paleozoic naticopsids form the stem group of modern Neritimorpha. This opinion was based only on similarities in teleoconch morphologies of post-Paleozoic Neritimorpha and Paleozoic Naticopsidae. Investigation of protoconch morphologies has revealed new data for both of the latter two groups. Naticopsid protoconchs are simple, smooth and orthostrophic (Yoo 1994, Nützel \& Mapes 2001, Bandel 2007, Nützel et al. 2007a), thus, they are similar to those found in some Silurian and Devonian "platyceratid" (see Fig. 4). It is noteworthy that there is no principal difference between this protoconch morphology and the protoconchs known in the Caenogastropoda (Nützel et al. 2007a, Frýda et al. 2008a). The oldest members of the Caenogastropoda (based on protoconch morphology) are documented from the Lower Devonian strata (Frýda 2001, Frýda \& Blodgett 2004, Cook et al. 2008) and they later formed a dominant group in the Late Paleozoic gastropod faunas (Knight 1933, Nützel 1998, Bandel 2002a, and references therein). Close similarities in the protoconch morphology of naticopsids and some "platyceratids" on one hand and caenogastropods on the other hand could indicate that the Neritimorpha and Caenogastropoda are closely related and that the convolute larval shell of the modern Neritimorpha is a relatively new feature (Nützel et al. 2007a, Frýda et al. 2008a).

Data on protoconch morphologies (orthostrophic protoconchs consisting of embryonic and larval shells) suggest that the Paleozoic Naticopsidae as well as some "platyceratids" may represent a stem group of modern Neritimorpha, as was already noted by Knight (1934). The occurrence of Late Triassic naticopsids having the same teleoconch features as undoubted Triassic neritimorphs (i.e., those having characteristic protoconchs only known in the neritimorph crown group among all living gastropods) also supports this model (Bandel 2007). If this is correct, then the Neritimorpha are a sister group of caenogastropods or all apogastropods and they had to have split from the caenogastropods before the Devonian (the oldest evidence for caenogastropods based on protoconch data). The typical neritimorph protoconch is an apomorphy only for the neritimorph crown group and it probably originated after the Permian/Triassic mass extinction event, but before the Late Triassic.

\section{Platyceratids as a stem group of patellogastropods}

A quite different opinion on the higher phylogenetic position of platyceratids was published by Ponder \& Lindberg (1997) based on data regarding their shell biomineralization which was published earlier by Carter \& Hall (1990). The latter authors found a regularly foliated shell microstructure in the Platyceratoidea. Except for the platyceratoids, this microstructure only occurs in living and fossil patellogastropods. Patellogastropoda are generally considered to represent a sister group to all other living gastropods (Golikov \& Starobogatov 1975, Lindberg 1988, Ponder \& Lindberg 1997, Aktipis et al. 2008). Living patellogastropods with limpet-shaped shells are exclusively marine and mostly occur on rocky shores in all continents. The oldest undoubted evidence for the Patellogastropoda is from Late Triassic strata (Hedegaard et al. 1997). The fact that there is no sure evidence for Paleozoic members of the Patellogastropoda is surprising because if they are really the first gastropod offshoot (Ponder \& Lindberg 1997), they had to have split off from the rest of the gastropods (i.e. orthogastropods) before the Early Ordovician (Frýda \& Rohr 2004, Frýda et al. 2008a). Thus, there is no certain fossil record for the first half of their presumed evolution as an independent gastropod clade (i.e., missing data for about $250 \mathrm{Ma}$ ). This controversy has been explai- 


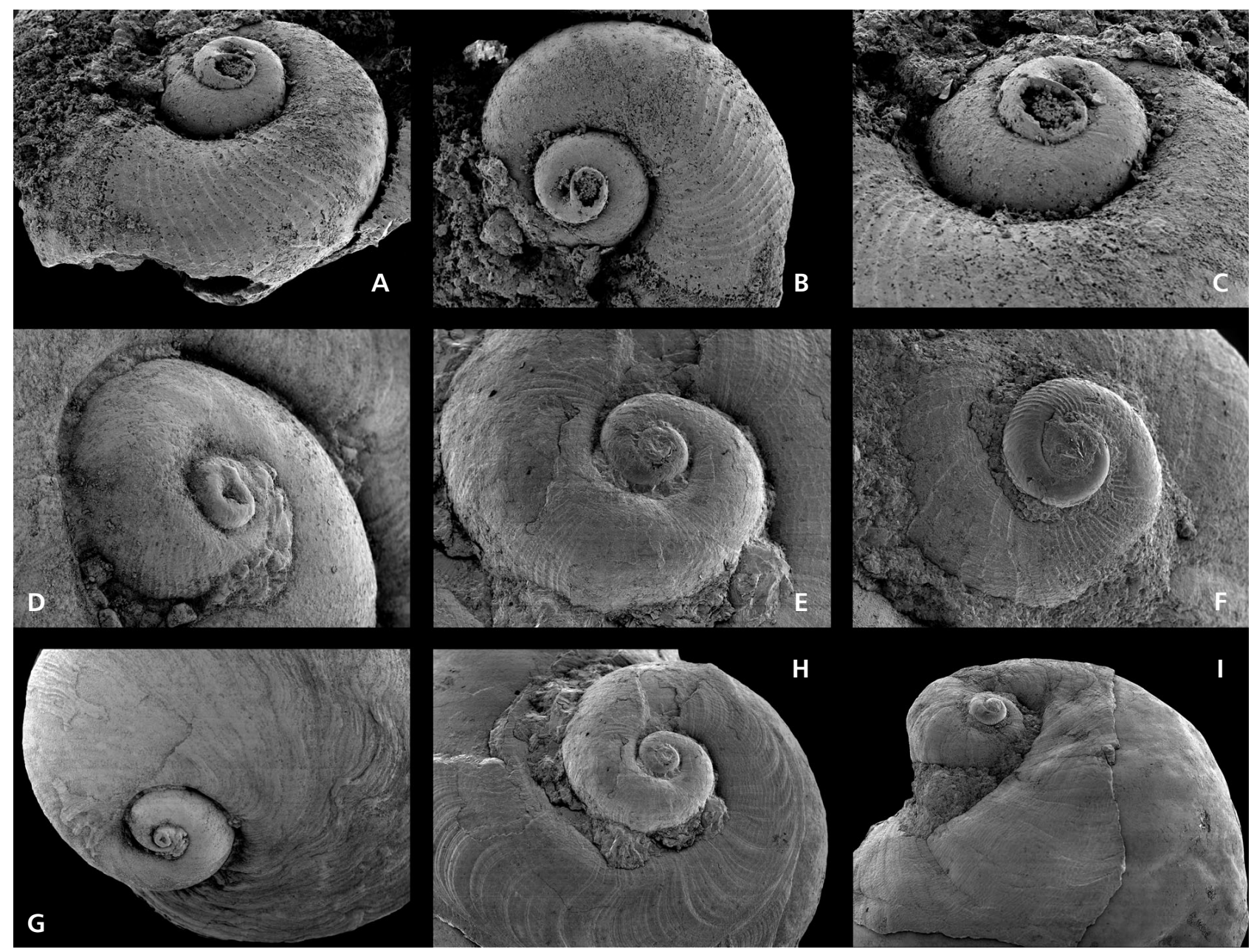

Figure 4. Protoconchs in the Silurian and Devonian platyceratids from the Barrandian area and Brittany. - A-C - orthostrophic, tightly coiled protoconch in Platyceras sp. from the Chýnice Limestone (middle Emsian) from the Čerinka locality near Bubovice (SW of Prague), specimen CGS JF 894, A × 60, B × 58, C × 105. D , G - cyrtoneritimorph protoconch in Praenatica cheloti (Oehlert \& Oehlert, 1887) from La Baconnière, topotype No. ML-PAL-00412, D $\times 27, \mathrm{G} \times 6$. $\bullet \mathrm{E}, \mathrm{H}$ - orthostrophic, tightly coiled juvenile whorl in the Late Silurian Platyceras sp. found close to the village of Lochkov (SW of Prague), specimen CGS JF 892, E × 27, H × 12. • F, I - orthostrophic, tightly coiled protoconch in another specimen of the Late Silurian Platyceras sp. found close to village of Lochkov (SW of Prague), specimen CGS JF 893, F × 30, I 6 .

ned by either their adaptation to intertidal environments that provide a relatively poor fossil record or by the opinion that the Paleozoic patellogastropods had coiled shells not hitherto recognized among Paleozoic gastropods. The nature of early patellogastropod shells is still a matter of debate. Haszprunar (1988) hypothesized that the limpet shell is a plesiomorphy retained by patellogastropods. However, Ponder \& Lindberg (1997; also Lindberg \& Ponder 2001) argued that this was a parallelism and that the last common ancestor of extant gastropods was coiled. Such an opinion had already been published by Knight (1952) who suggested that the patellogastropods were derived from the pleurotomarioids. This model seems to fit with the protoconch nature of both groups (absence of true larval shell). If this model will be accepted then the very complex microstructure of the patellogastropod shells (MacClintock 1968,
Bandel \& Geldmacher 1996, Sasaki 1998, Fuchigami \& Sasaki 2005) had to be secondarily evolved, maybe because of their adaptation to intertidal environments.

The phylogenetic model which considers platyceratoideans to represent possible coiled ancestors for the patellogastropods is only supported by the above-mentioned sharing of regularly foliated shell microstructure. However, there are some doubts if this microstructure is really identical in both groups (see Bandel \& Geldmacher 1996). In addition, we see a more serious fact which testifies against this phylogenetic model - the nature of early shell ontogeny in both groups. The patellogastropods share the same pattern of early shell ontogeny with archaeogastropods such as the Vetigastropoda (Bandel 1982, Sasaki 1998), developing their protoconchs without a true larval shell (protoconch II). This strategy was documented 


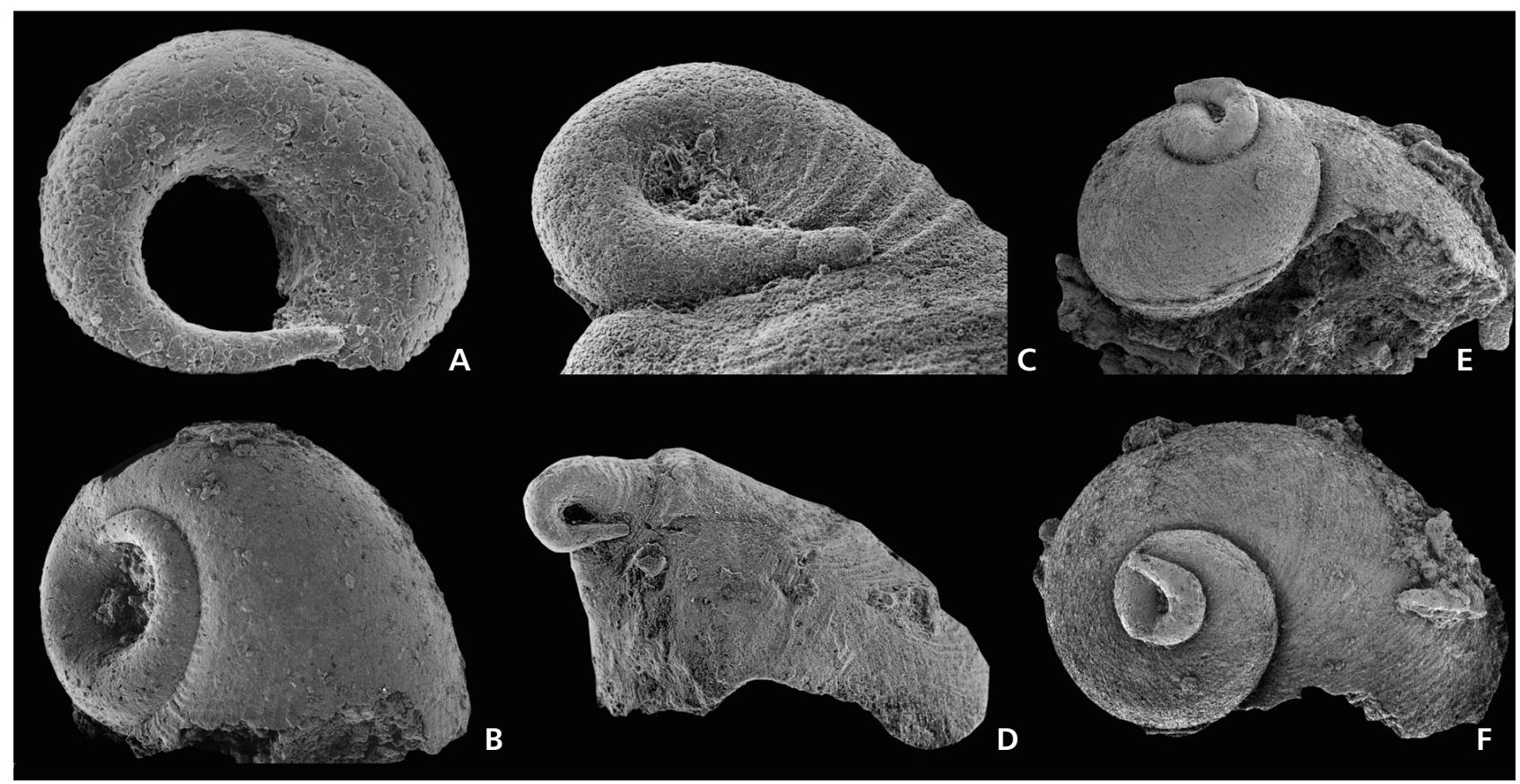

Figure 5. Protoconchs in the Devonian and Carboniferous cyrtoneritimorph gastropods. $\bullet A-D-$ cyrtoneritimorph larval shell (A) and early teleoconch (B) in the Early Devonian (Lochkovian) Vltaviella reticulata Frýda \& Manda, 1997, SW Prague, A × 55, B × 32. C , D - cyrtoneritimorph protoconch larval shell (C) and teleoconch (D) in the Carboniferous Orthonychia parva (Shumard \& Swallow, 1858) from the St. Louis outlier of the Des Moines group in the Pennsylvanian of Missouri, C × 60, D × 20. • E, F - teleoconch in Middle Devonian Eifelcyrtus blodgetti Frýda \& Heidelberger, 2003, from the Scheid Member of the Cuerten limestone (early Givetian, late Middle Devonian; Soetenicher Mulde), E × 30, F × 32 .

to be stable for at least the last $400 \mathrm{Ma}$ in the case of archaeogastropods (Frýda 1999, Frýda et al. 2008a). On the other hand, both groups of platyceratids (cyrtoneritimorph "platyceratids" as well as "platyceratids" having tightly coiled protoconchs) as well as the naticopsids, developed true larval shells (protoconch II). Thus, if the platyceratoids are a stem group of the patellogastropods, then the patellogastropods had to lose the ability to develop true larval shells (protoconch II) during the Late Paleozoic or Early Triassic. Taken together, the interpretation of platyceratoid gastropods as the stem group of patellogastropods based on sharing of the same shell microstructure is in conflict with the pattern of their early shell ontogeny.

Two years ago Sutton et al. (2006) reported the discovery of an unusually well preserved gastropod with fossilized soft tissues from the Lower Silurian (Wenlock Series) Herefordshire Lagerstätte of England. This gastropod was assigned to the Platyceratidae on the basis of its simple subcircular aperture, trochiform shell and the absence of ornamentation. Its study has revealed detailed data on the digestive system as well as morphological data on the gonads, digestive gland, pedal muscle, radula, mouth and foot. According to Sutton et al. (2006) the digestive system is the most informative phylogenetically of all the preserved soft-tissue characters. These anatomical data together with the absence of the operculum were interpreted as suggesting that platyceratids were symbiotic rather than predatory on their hosts. However, a more important conclusion made by Sutton et al. (2006) is that anatomical characters of their Platyceras? sp. suggest its patellogastropod affinity rather than neritopsine $[=$ neritimorph] affinity. However, this undoubtedly important discovery includes one serious problem. Unfortunately teleoconch features (simple subcircular aperture, trochiform shell and absence of shell ornamentation) used for assignement of the gastropod from the Herefordshire Lagerstätte to the platyceratids are not sufficient for such a taxonomical conclusion. Similar teleoconch shapes may be found in several unrelated Paleozoic gastropods because the severe architectural restrictions caused a common occurrence of morphological convergence in their teleoconchs (see Wenz 1938-1944, Knight et al. 1960). In contrast to the teleoconch features, the protoconch morphology might be diagnostic of large gastropod clades. By courtesy of M.D. Sutton (pers. comm., 2008) we had the chance to examine in detail the apical view of a shell from the Herefordshire Lagerstätte (Sutton et al. 2006, fig. 1f). Unfortunately no traces of protoconch morphology were observed. The discovery made by Sutton et al. (2006) is important for the interpretation of the patellogastropod phylogeny (the Silurian gastropod from the Herefordshire Lagerstätte may represent a coiled ancestor of the Patellogastropoda), but cannot be used as evidence for platyceratid and patellogastropod affinity. 


\section{Conclusions}

New discoveries of protoconch morphologies contribute to our knowledge of platyceratid phylogeny. Several key points relating to this problem are summarized below:

1. Species of the Early Devonian platyceratid Praenatica Barrande in Perner, 1903 developed a typical cyrtoneritimorph protoconch. The same protoconch type was earlier documented in Orthonychia Hall, 1843. Both of these taxa have often been considered to be subgenera of Platyceras Conrad, 1840.

2. Quite different protoconch morphology (orthostrophic and tightly coiled) was recently documented in some $\mathrm{Si}$ lurian and Devonian species placed in the genus Platyceras. The same type of the protoconch was earlier found in different species of the Naticopsidae.

3. The present data thus suggests that Paleozoic platyceratids represent a diphyletic group. However, development of true larval shells in both "platyceratid" groups argues against the hypothesis that Paleozoic platyceratids represent a stem group for the Patellogastropoda.

4. Paleozoic evolution of the neritimorph clade is uncertain, but their derivation from the Paleozoic "platyceratids" with tightly coiled protoconchs or from the naticopsids seems to be probable. A strongly convolute neritimorph protoconch (apomorphy of the neritimorph crown-group) probably originated after the Permian/Triassic mass extinction event and but before the Late Triassic.

\section{Acknowledgements}

This work was supported by grants from the Grant Agency of the Czech Republic (205/08/0062), the Czech-American Cooperation Program (Kontakt ME08011), and a CGS grant (3325). The revision of Lower Devonian gastropods from the Massif Armoricain was made possible through an invited professorial position for J. Frýda at the Université de Bretagne Occidentale (Brest) in April 2008. The authors thank Doris Heidelberger (Oberursel), Robert B. Blodgett (Anchorage), and Wojciech Krawczyński (Sosnowiec) for their helpful reviews. The authors also thank Jessica Cundiff (Curator of the Schary collection, Museum of Comparative Zoology, Harvard) and Jérôme Treguier (Curator of the Oehlert's collection, Musée d'Histoire Naturelle, Laval) for providing the material used in this study.

\section{References}

AKTIPIS, S.W., GIRIBET, G., LindBerG, D.R. \& PONDER, W.F. 2008. Gastropoda - an overview and analysis, 201-237. In PONDER, W. \& LindBerg, D.L. (eds) Phylogeny and Evolution of the Mollusca. 488 pp. University of California Press, Berkeley \& Los Angeles, California.
BANDEL, K. 1982. Morphologie und Bildung der frühontogenetischen Gehäuse bei conchiferen Mollusken. Fazies 7, $1-198$.

BANDEL, K. 1992. Platyceratidae from the Triassic St. Cassian Formation and the evolutionary history of the Neritomorpha (Gastropoda). Paläontologische Zeitschrift 66, 231-240.

BANDEL, K. 1997. Higher classification and pattern of evolution of the Gastropoda. Courier Forschungsinstitut Senckenberg $201,57-81$.

BANDEL, K. 2002a. Reevaluation and classification of Carboniferous and Permian Gastropoda belonging to the Caenogastropoda and their relation. Mitteilungen Geologie-Paläontologie Institut der Universität Hamburg 86, 81-188.

BANDEL, K. 2002b. About the Heterostropha (Gastropoda) from the Carboniferous and Permian. Mitteilungen Geologie-Paläontologie Institut der Universität Hamburg 86, 45-80.

BANDEL, K. 2007. Description and classification of Late Triassic Neritimorpha (Gastropoda, Mollusca) from St. Cassian Formation, Italian Alps. Bulletin of Geosciences 82(3), 215-274. DOI 10.3140/bull.geosci.2007.03.215

BANDEL, K. 2008. Operculum shape and construction of some fossil Neritimorpha (Gastropoda) compared to those of modern speces of the subclass. Vita Malacologica 7, 19-36.

BANDEL, K. \& FRÝDA, J. 1998. Position of Euomphalidae in the system of the Gastropoda. Senckenbergiana Lethaea 78, 103-131.

BANDEL, K. \& FRÝDA, J. 1999. Notes on the evolution and higher classification of the subclass Neritimorpha (Gastropoda) with the description of some new taxa. Geologica et Palaeontologica 33, 219-235.

BAndel, K. \& Heidelberger, D. 2001. The new family Nerrhenidae (Neritimorpha, Gastropoda) from the Givetian of Germany. Neues Jahrbuch für Geologie und Paläontologie, Monatshefte 12, 705-718.

BANDEL, K. \& GELDMACHER, W. 1996. The structure of the shell of Patella crenata connected with suggestions to the classification and evolution of the Archaeogastropoda. Freiberger Forschungsheft C 464, 1-71.

BATTEN, R.L. 1984. Neopilina, Neomphalus, and Neritopsis, living fossil mollusks, 218-224. In ELDREDGE, N. \& STANLEY, S.M. (eds) Living Fossils. Springer, New York.

BIGSBY, J.J. 1868. Thesaurus siluricus. The Flora and Fauna of the Silurian Period. I-LII, 1-214 pp. London.

BLODGETT, R.B. \& JoHnson, J.G. 1992. Early Middle Devonian (Eifelian) gastropods of central Nevada. Palaeontographica, Abteilung A 222, 85-139.

BOUCHET, P., ROCROI, J.P., FRÝdA, J., HAUSDORF, B., PONDER, W., VALDES, A. \& WARÉN, A. 2005. Classification and nomenclator of gastropod families. Malacologia 47(1-2), $1-368$.

CARls, P., SlavíK, L. \& VAlenZuela-Ríos, J.I. 2008. Comments on the GSSP for the basal Emsian stage boundary: the need for its redefinition. Bulletin of Geosciences 83(4), 383-390. DOI 10.3140/bull.geosci.2008.04.383

CARTER, J.G. \& HALl, R.M. 1990. Part 3. Polyplacophora, Scaphopoda, Archaeogastropoda and Paragastropoda (Mollusca). 
In CARTER, J.G. (ed.) Skeletal Biomineralisation: Patterns, Processes and evolutionary trends. Vol. II. Atlas and Index. New York: Van Nostrand Reinhold, 29-51, pls 122-134.

Colgan, D.J., PONDER, W.F., BEACHAM, E. \& MACARANAS, J.M. 2003. Gastropod phylogeny based on six segments from four genes representing coding or non-coding and mitochondrial or nuclear DNA. Molluscan Research 23(2), 123-148. DOI 10.1071/MR03002

CONRAD, T.A. 1840. Third Annual Report on the Paleontological Department of the Survey. New York Geological Survey, Annual Report 4, 199-207.

CONRAD, T.A. 1842. Observations on the Silurian and Devonian Systems of the United States, with descriptions of new organic remains. Journal of the Academy of Natural Sciences of Philadelphia 8, 228-280.

COOK, A., NÜTZEL, A. \& FrÝDA, J. 2008. Two Mississippian caenogastropod limpets from Australia and their meaning for the ancestry of the Caenogastropoda. Journal of Paleontology 82(1), 183-187. DOI 10.1666/06-028.1

FISCHER, P. 1885. Manuel de conchyliologie et de paléontologie conchyliologique, ou histoire naturelle des molluscques vivants et fossiles. Fascicle VIII. pp. 1-1369. Savy, Paris.

FRÝDA, J. 1998a. Did the ancestors of higher gastropods (Neritimorpha, Caenogastropoda, and Heterostropha) have an uncoiled shell?, 107. In BIELER, R. \& MiKKELSEN, P.M. (eds) Abstracts, World Congress of Malacology. UNITAS Malacologica, Chicago.

FRÝDA, J. 1998b. Higher classification of the Paleozoic gastropods inferred from their early shell ontogeny, 108. In BIELER, R. \& MiKKelsen, P.M. (eds) Abstracts, World Congress of Malacology. UNITAS Malacologica, Chicago.

FRÝDA, J. 1998c. Classification and phylogeny of Devonian gastropods. 187 pp., 28 pls. PhD Thesis, Universität Hamburg, Hamburg.

FRÝDA, J. 1999. Higher classification of Paleozoic gastropods inferred from their early shell ontogeny. Journal of the Czech Geological Society 44, 137-152.

FRÝDA, J. 2001. Discovery of a larval shell in Middle Paleozoic subulitoidean gastropods with description of two new species from the Early Devonian of Bohemia. Bulletin of the Czech Geological Survey 76(1), 29-37.

FRÝDA, J. \& BLODGETT, R.B. 2004. New Emsian (late Early Devonian) gastropods from Limestone Mountain, Medfra B-4 quadrangle, west-central Alaska (Farewell terrane), and their paleobiogeographic affinities and evolutionary significance. Journal of Paleontology 78(1), 111-132. DOI 10.1666/0022-3360(2004)078<0111:NELEDG >2.0.CO;2

FRÝDA, J. \& HEIDELBERGER, D. 2003. Systematic position of Cyrtoneritimorpha within class Gastropoda with description of two new genera from Siluro-Devonian strata of Central Europe. Bulletin of Geosciences 78(1), 35-39.

FRÝDA, J. \& MANDA, Š. 1997. A gastropod faunule from the Monograptus uniformis graptolite Biozone (Early Lochkovian, Early Devonian) in Bohemia. Mitteilungen Geologie-Paläontologie Institut der Universität Hamburg 80, 59-121.
FRÝDA, J., NÜTZEL, A. \& WAGNER, P.J. 2008a. Paleozoic gastropods, 237-268. In PONDER, W. \& LINDBERG, D.L. (eds) Phylogeny and Evolution of the Mollusca. 466 pp. University of California Press, Berkeley \& Los Angeles, California.

FRÝdA, J., RACHEBOEUF, P.R. \& FRÝdOVÁ, B. 2008b. Mode of life of Early Devonian Orthonychia protei (Neritimorpha, Gastropoda) inferred from its post-larval shell ontogeny and muscle scars. Bulletin of Geosciences 83(4), 491-502.

DOI 10.3140/bull.geosci.2008.04.491

FRÝDA, J. \& ROHR, D.M. 2004. Gastropoda, 184-195. In Webby, B.D., PARIS, F., Droser, M.L. \& Percival, I.G. (eds) The Great Ordovician Biodiversification Event. 408 pp. Columbia University Press, New York.

FRÝDA, J. \& ROHR, D.M. 2006. Shell heterostrophy in Early Ordovician Macluritella Kirk, 1927, and its implications for phylogeny and classification of Macluritoidea (Gastropoda). Journal of Paleontology 80(2), 264-271. DOI 10.1666/0022-3360(2006)080[0264:SHIEOM]2.0.CO;2

FUCHIGAMI, T. \& SASAKI, T. 2005. The shell structure of the Recent Patellogastropoda (Mollusca: Gastropoda). Palaeontological Research 9, 143-168. DOI 10.2517/prpsj.9.143

Golikov, A.N. \& StaRobogATOV, Y.I. 1975. Systematics of prosobranch gastropods. Malacologia 15, 185-232.

HALL, J. 1843. Geology of New York. Part IV, comprising the survey of the fourth geological district. Natural History of New York 4, 1-683.

HALL, J. 1859. Contributions to the palaeontology of New York; being some of the results of the investigations during the years 1855, 1856, 1857, and 1858. Twelfth Annual Report of the Regents of the University of the State of New York on the condition of the State Cabinet of Natural History and the Historical and Antiquarian Collection Connected Therewith, 8-110.

HALL, J. 1861. Descriptions of new species of fossils from the investigations of the Survey. Geological Survey of Wisconsin Progress Report 1861, 11-52.

HALL, J. 1879. Natural History of New York. Geological Survey of New York. Palaeontology, vol. 5, part 2. 492 pp. Van Benthuysen, Albany.

HASZPRUNAR, G. 1988. On the origin and evolution of major gastropod groups, with special reference to the Streptoneura. Journal of Molluscan Studies 54, 367-441.

DOI 10.1093/mollus/54.4.367

HASZPRUNAR, G. 1995. On the evolution of larval development in the Gastropoda, with special reference to larval planktotrophy. Notiz CISMA, XVI, 5-13.

HEALEY, J.M. 1988. Sperm morphology and its systematic importance in the Gastropoda. In PONDER, W.F. (ed.) Prosobranch phylogeny. Malacological Review, Supplement 4, 251-266.

HedegaARD, C., LindBerG, D.R. \& BANDEL, K. 1997. Shell microstructure of a Triassic patellogastropod limpet. Lethaia 30, 331-335.

HeIDELBERGER, D. \& BANDEL, K. 1999. Micromorph Gastropoda from the Middle Devonian (Givetian) limestone of the Sötenich Syncline (Eifel). Mitteilungen Geologie-Paläontologie Institut der Universität Hamburg 83, 129-162. 
HORNÝ, R.J. \& HENRY, J.-L. 1999. A letter by Joachim Barrande to Daniel Oehlert concerning Praenatica (Gastropoda) written on May 12, 1882. Journal of the Czech Geological Society, 44(1-2), 117-125.

KAIM, A. \& SZTAJNER, P. 2005. The opercula of neritopsid gastropods and their phylogenetic importance. Journal of Molluscan Studies 71, 1-9. DOI 10.1093/mollus/eyi029

KANO, Y. 2006. Usefulness of the opercular nucleus for inferring early development in neritimorph gastropods. Journal of Morphology 267, 1120-1136. DO1 10.1002/jmor.10458

KANO, Y., CHIBA, S. \& KASE, T. 2002. Major adaptive radiation in neritopsine gastropods estimated from $28 \mathrm{~S}$ rRNA sequences and fossil records. Proceedings of the Royal Society of London B 269, 2457-2465. DOI 10.1098/rspb.2002.2178

KIRCHNER, H.S. 1915. Mitteldevonische Gastropoden von Soetenich in der Eifel. Verhandlungen des Naturhistorschen Vereins der Preufsischen Rheinlande und Westfalens 1914, 189-261.

KNIGHT, J.B. 1933. The gastropods of the St. Louis, Missouri, Pennsylvanian outlier: VI. The Neritidae. Journal of Paleontology 7, 359-392.

KNIGHT, J.B. 1934. The gastropods of the St. Louis, Missouri, Pennsylvanian outlier: VII, the Euomphalidae and Platyceridae. Journal of Paleontology 8, 139-166.

KNIGHT, J.B. 1941. Paleozoic gastropod genotypes. Geological Society of America Special Paper 32, 1-510.

KNIGHT, J.B. 1952. Primitive fossil gastropods and their bearing on gastropod classification. Smithsonian Miscellaneous Collections 117(13). 56 pp. Smithsonian Institute, Washington.

Knight, J.B., Cox, L.R., BAtTEn, R.L. \& Yochelson, E.L. 1960. Systematic descriptions. In MOORE, R.C. (ed.) Treatise on invertebrate paleontology. Part I. Mollusca 1. University of Kansas Press, Lawrence, Kansas.

KŘíž, J. \& LUKEŠ, P. 1974. Color pattern on Silurian Platyceras and Devonian Merista from the Barrandian area, Bohemia, Czechoslovakia. Journal of Paleontology 48(1), 41-48.

LAUBE, G.C. 1869. Die Fauna der Schichten von St. Cassian. III. Abtheilung. Gastropoden. II. Hälfte. Denkschriften der Kaiserlichen Akademie der Wissenschaften, Mathematischnaturwissenschaftliche Klasse 30, 1-48.

LINDBERG, D.R. 1988. The Patellogastropoda. In PONDER, W.F. \& WARÉN, A. (eds) Prosobranch phylogeny: proceedings of the $9^{\text {th }}$ International Malacological Congress. Malacological Review 4, 35-63.

LINDBERG, D.R. \& PONDER, W.F. 2001. The influence of classification of the evolutionary interpretation of structure - a reevaluation of the evolution of the pallial cavity of gastropod molluscs. Organisms, Diversity and Evolution 1, 273-299. DOI 10.1078/1439-6092-00025

MCARTHUR, A.G. \& HARASEWYCH, M.G. 2003. Molecular systematics of the major lineages of the Gastropoda, 140-160. In LYDEARD, C. \& LINDBERG, D.R. (eds) Molecular systematics and phylogeography of mollusks. 312 pp. Smithsonian Books, Washington.

MACCLINTOCK, C. 1968. Shell structure of patelloid and bellerophontoid gastropods (Mollusca). Peabody Museum of Natural History Bulletin 22, 1-140.

M'CoY, F. 1844. A synopsis of the characters of the Carboniferous limestone fossils of Ireland. 207 pp. Dublin.

MoRZADEC, P. 1971. Quelques Asteropyginæ (Trilobites, Phacopacea) des schistes et calcaires à Athyris undata (Dévonien inférieur) du Massif Armoricain. Palaeontographica A 138, 166-184.

MunieR-CHALmas, E. 1876. Mollusques nouveaux des terrains paléozoiques des environs de Rennes. Journal de Conchyliologie, $3^{e}$ series 16, 102-109.

NÜTZEL, A. 1998. Über die Stammesgeschichte der Ptenoglossa (Gastropoda). Berliner Geowissenschaftliche Abhandlungen, Reihe E 26, 1-229.

NÜTZEL, A. 2002. An evaluation of the recently proposed Palaeozoic gastropod subclass Euomphalomorpha. Palaeontology 45, 259-266. DOI 10.1111/1475-4983.00236

NÜTZEL, A., ERWIN, D.H. \& MAPES, R.H. 2000. Identity and phylogeny of the late Paleozoic Subulitoidea (Gastropoda). Journal of Paleontology 74, 575-598. DOI 10.1666/0022-3360(2000)074<0575:IAPOTL >2.0.CO;2

NÜTZEL, A. \& FRÝDA, J. 2003. Paleozoic plankton revolution: evidence from early gastropod ontogeny. Geology 31, 829-831. DOI $10.1130 / \mathrm{G} 19616.1$

NÜtZel, A., FrÝdA, J., YANCEY, T.E. \& ANDERSON, J.R. 2007a. Larval shells of Late Palaeozoic naticopsid gastropods (Neritopsoidea: Neritimorpha) with a discussion of the early neritimorph evolution. Paläontologische Zeitschrift 81(3), 213-228.

NÜTZEL, A., LEHNERT, O. \& FRÝDA, J. 2006. Origin of planktotrophy - evidence from early molluscs. Evolution and Development 8(4), 325-330.

DOI 10.1111/j.1525-142X.2006.00105.x

NÜTZEL, A., LEHNERT, O. \& FRÝDA, J. 2007b. Origin of planktotrophy - evidence from early molluscs: a response to Freeman and Lundelius. Evolution and Development 9(4), 312-317. DOI 10.1111/j.1525-142X.2007.00166.x

NÜTZEL, A. \& MAPES, R.H. 2001. Larval and juvenile gastropods from a Mississippian black shale: Paleoecology, and implications for the evolution of the Gastropoda. Lethaia 34, 143-162. DOI 10.1080/00241160152418447

OEHLERT, D. 1877. Sur les fossiles dévoniens du département de la Mayenne. Bulletin de la Société géologique de France 3(5), 578-603.

OEHLERT, D. 1881. Documents pour servir à l'étude des faunes dévoniennes dans l'ouest de la France. Mémoires de la Sociéte Géologique de France 3(2), 1-38.

OEHLERT, D. 1883. Description de deux nouvelles espèces d'Acroculia du Dévonien inférieur de la Mayenne. Bulletin de la Société géologique de France 3(11), 602-609.

OehleRT, D. \& Davoust, P. 1879. Sur le Dévonien du Département de la Sarthe. Bulletin de la Société géologique de France 7, 697-717.

OeHLERT, D. \& OeHLERT, P. 1887. Descriptions de quelques espèces dévoniennes du département de la Mayenne. Bulletin de la Société d'Etudes Scientifiques d'Angers 1887, 65-120. 
PERNER, J. 1903. Recherches paléontologiques. Volume 4, Gastéropodes. In BARRANDE, J. Système silurien du centre de la Bohême. Prague.

PONDER, W.F. \& LINDBERG, D.R. 1997. Towards a phylogeny of gastropod molluscs: an analysis using morphological characters. Zoological Journal of the Linnean Society 119, 83-265. DOI 10.1111/j.1096-3642.1997.tb00137.x

RACHEBOeUf, P.R. 1976. Chonetacea (Brachiopodes) du Dévonien inférieur du Bassin de Laval (Massif Armoricain). Palaeontographica A 152, 14-89.

RENAUD, A. 1930. Etude de la faune des calcaires dévoniens de bois-Roux. Bulletin de la Société Géologique et Minéralogique de Bretagne 9(1928), 141-292.

Renaud, A. 1942. Le Dévonien du Synclinorium Médian BrestLaval. Mémoires de la Société géologique et minéralogique de Bretagne 7(1), 1-184 (Stratigraphie), (2), 1-439 (Paléontologie).

SASAKI, T. 1998. Comparative anatomy and phylogeny of the Recent Archaeogastropoda. The University Museum, The University of Tokyo, Bulletin 38, 1-223.

Shumard, B.F. \& Swallow, G.C. 1858. Descriptions of new fossils from the Coal Measures of Missouri and Kansas. Academy of Science of St. Louis Transactions 1, 198-227

SOWERBY, J. DE C. 1829. No. CIV of the mineral conchology of Great Britain; or colored figures and descriptions of those remains of testaceous animals or shells, which have been preserved at various times and depths in the Earth. The mineral conchology of Great Britain 6(54), 201-230.

STANLEY, S.M. 2007. An analysis of the history of marine animal diversity. Paleobiology 33, Supplement 4, 1-55. DOI $10.1666 / 06020.1$
Sutton, M.D., BRiggs, D.E.G., Siveter, D.J. \& Siveter, D.J. 2006. Fossilized soft tissues in a Silurian platyceratid gastropod. Proceedings of the Royal Society B: Biological Sciences 273(1590), 1039-1044.

THIELE, J. 1929-35. Handbuch der systematischen Weichtierkunde. 1154 pp. Fischer, Jena.

Troschel, F.H. 1856. Das Gebiss der Schnecken zur Begründung einer natürlichen Classification. Band 1. $252 \mathrm{pp}$. Nicolaische Verlagsbuchhandlung, Berlin.

VERNEUIL, E. DE. 1850. Note sur les fossiles dévoniens du district de Sabero (Léon). Bulletin de la Société géologique de France 2(7), 155-186.

WAagen, W. 1880. Salt-Range fossils. I, Productus-limestone fossils. 2, Pisces-Cephalopoda: supplement. Gasteropoda. Memoirs of the Geological Survey of India. Palaeontologia Indica 13, 73-183.

WENZ, W. 1938-1944. Gastropoda, 1-1639. In SCHINDEWOLF, O.H. (ed.) Handbuch der Paläozoologie, Band 6, Teil 1-7. Borntraeger, Berlin.

YOCHELSON, E.L. 1956. Permian gastropods of the southwestern United States, Pt. I. Euomphalacea, Trochonematacea, Pseudophoracea, Anomphalacea, Craspedostomatacea, and Platyceratacea. American Museum of Natural History, Bulletin 110, 170-260.

YOCHELSON, E.L. \& Kříž, J. 1974. Platyceratid gastropods from the Oriskany Sandstone (Lower Devonian) near Cumberland, Maryland: Synonymies, preservation and color markings. Journal of Paleontontology 48, 474-483.

YoO, E.K. 1994. Early Carboniferous Gastropoda from the Tamworth Belt, New South Wales, Australia. Records of the Australian Museum 46, 63-120. 